УДК 655:686.1.033

(C)

О. І. Лотоцька, к.т.н., доцент, НТУУ «КПІ», Київ, Україна

\title{
ДОСЛІДЖЕННЯ ВПЛИВУ ТЕХНОЛОГІЧНИХ ФАКТОРІВ ДЛЯ ОЦІНЮВАННЯ ЯКОСТІ ГАРЯЧОГО ТИСНЕННЯ ФОЛЬГОЮ НА ПЛАСТИКОВИХ МАТЕРІАЛАХ
}

\section{У статті проведено аналіз показників якості тиснення фольгою зразків з полівінілхлориду при різних технологічних режимах. Встановлено найбільш оптимальні параметри для отримання якісних відбитків.}

\begin{abstract}
Ключові слова: тиснення; фольга; полівінілхлорид; штамп; роздільна здатність; покривна здатність; адгезія; стійкість до стирання.
\end{abstract}

\section{Постановка проблеми}

Поряд з усіма своїми перевагами процес тиснення на пластику має і свої труднощі, головною 3 яких $є$ підбір режимів тиснення, оскільки від правильного підбору режимів тиснення залежить якість отриманого відбитка. Ця проблема торкається кожного, хто стикається з процесом тиснення, особливо при отриманні нових матеріалів і нових серій фольги.

Аналізуючи процес тиснення фольгою, потрібно звернути увагу на ті фактори, які впливають на якість відбитка. До них відносяться: товщина і теплопровідність основи фольги, температура штампа, швидкість тиснення, час контакту штампа 3 фольгою, площа друкувальних елементів штампа, конфігурація штампа, товщина штампа, товщина прокладки між гарячою плитою преса і штампом, відповідність адгезійного шару фольги поверхні задруковувано- го матеріалу, утворюваний тиск $[1,2]$.

Основне завдання, яке стоїть перед нами - знайти таке оптимальне співвідношення технологічних режимів, яке б забезпечило найвищі показники якості, до яких віднесли роздільну та покривну здатність, стійкість до стирання, дослідження адгезії та чіткості зображення, графічне спотворення [3]. Тому визначення оптимального співвідношення технологічних факторів тиснення $€$ актуальною задачею.

\section{Аналіз попередніх досліджень}

Знаходження принципового рішення між технологічними режимами та якістю - основна задача, яку потрібно вирішувати для отримання оптимальних результатів при гарячому тиснені на полівінілхлориді (ПВХ).

Основним фактором, якими можна керувати при тисненні є: тиск тиснення, температура

(c) $2016 \mathrm{p}$. 
штампу і час контакту штампу із задрукованим матеріалом [1, 2]. Різні види фольги, рекомендовані для певних матеріалів, потребують різних температурних режимів. Це обумовлено як температурою пом'якшення адгезійного шару, так і температурою пом'якшення поверхневого шару матеріалу виробу. Але в кожному з цих випадків температура штампа в період роботи має бути постійною. Допустиме відхилення 5-7 \%.

Зі збільшенням температури штампа міцність закріплення фольги на матеріалі збільшується, але це відбувається в певному температурному інтервалі. Адже з підвищенням температури роздільний шар фольги відокремлюється для формування зображення, а адгезійний - приклеюється до ПВХ [4]. При недостатній температурі штампа відбувається неповна передача шару фольги на виріб, а перегрів кліше може спричинити до плавлення поверхневих шарів матеріалу, а також до зміни кольору та втрати дрібних елементів і блиску зображення на пластику $[1,5]$.

Для отримання щільного контакту між пластиком і фольгою потрібен певний тиск. При тисненні фольгою тиск повинен забезпечити надійне закріплення фарбового шару фольги і отримання чітких контурів графічних елементів зображення при мінімальній глибині тиснення [5]. Недоліки виявлені в процесі тиснення можна виправити шляхом підвищення тиску. Зі збільшенням тиску при тисненні фольгою на непористих матеріалах міцність закріплення фольги на ма- теріалі зростає. При значному збільшенні тиску міцність закріплення залишається практично незмінною [1]. Баланс досягається, коли установлена певна величина тиску, достатня для хорошої передачі шару фольги, в той же час зберігається чисте зображення. Відповідно до опублікованих досліджень [6] тиск має менший вплив на якість відбитка ніж температура. Недостатня величина тиску може призвести до неповного переходу фарбового шару з основи поліграфічної фольги, а збільшення тиску - до надлишку фарбового шару на пробільних елементах зображення, а також до руйнування матеріалу $[1,5]$.

Ще одним 3 керованих технологічних режимів $€$ час тиснення, в період якого штамп контактує з фольгою та пластиком. Збільшення часу витримки зазвичай покращують якість приклеювання, після чого зображення стає більш чистим. Визначено [7], що збільшення часу контакту штампа з матеріалом дозволяє знизити величину тиснення. За даними літературних джерел [2, 8] рекомендовано час контакту кліше із задрукованим матеріалом витримувати в межах 0,5 до 5 с.

Найбільш значимим параметром, який впливає на якість згладжування поверхні покривного матеріалу, є температура, в меншій мірі - тиск і ще в меншій - швидкість [7].

Отже, вибір оптимальних технологічних режимів при тисненні на ПВХ виконувався для конкретних умов на основі практичного і експериментального досліджень. 


\section{Мета роботи}

Метою роботи є дослідження основних показників якості тиснення фольгою на ПВХ при різних технологічних режимах, які б забезпечили високу якість поліграфічного відтворення.

\section{Результати проведених досліджень}

Якісне тиснення фольгою повинно мати: чітке відтворення контурів, графічну точність відтворення малюнка штампа, повне заповнення товстих ліній i плашок. Нечітке тиснення країв може виникати при неправильно виставленій температурі або занадто високому тиску [9]. Недостатня в деяких випадках якість тиснення проявляється в тому, що колірний шар фольги закріплюється не лише в місцях дії друкувальних елементів штампа, а й на прогалинних ділянках відбитка [10].

У тестових шкалах для експериментального дослідження процесу гарячого тиснення фольгою присутні два показники за якими контролюється якість тиснення: здатність відтворювати штрихи певної товщини та коефіцієнт заповнення плашки для оцінювання відтворення значних площ [1]. Перший показник визначається властивостями кліше і залежить від його матеріалу та способу виготовлення, а також дозволяє оцінити спотворення ширини штриха на відбиткові порівняно з оригіналом [10].

Для оцінки впливу технологічних факторів на якість тиснення проведено експериментальні дослідження на автоматичному пресі для тиснення РМ3000-СС 3 використанням фольги Alufin SHC 90 0,08×122 м фірми KURZ срібного кольору на ПВХ.

Результати дослідження покривної здатності відбитка (табл.). Покривна здатність фольги характеризує ступінь задруковування фольгою на ПВХ під друкувальними елементами. Відбиток вважається якісним за покривною здатністю у тому випадку, якщо фарбовий шар фольги повністю заповнює відбиток плашкою. Покривну здатність оцінювали візуально за шестибальною системою [1, $2,10]$.

На рис. 1 представлено зразки 3 найнижчою покривною здатністю 0,5 балів при температурі $110^{\circ} \mathrm{C}$, тиском $4 \mathrm{MПа,} \mathrm{час}$

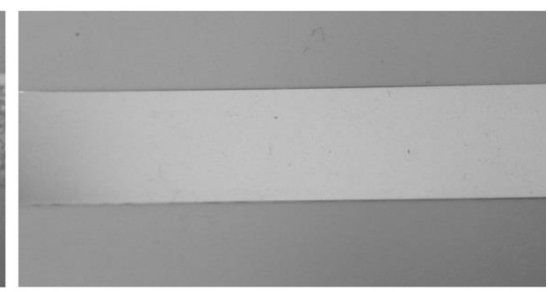

б

Рис. 1. Відбитки після гарячого тиснення а - при температурі $110^{\circ} \mathrm{C}$, тиском 4 МПа, час 0,01 c; б - при температурі $155^{\circ} \mathrm{C}$ з тиском $5 \mathrm{MПа,}$ час $1,5 \mathrm{c}$ 


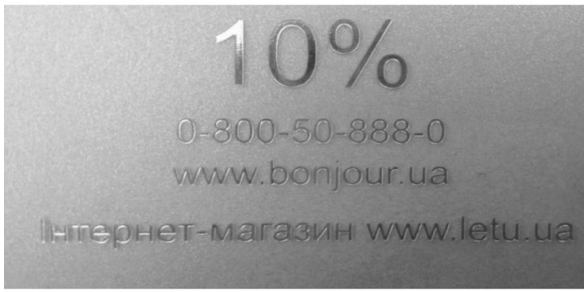

a

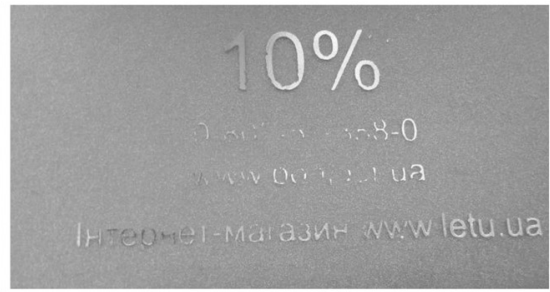

б

Рис. 2. Відбитки після гарячого тиснення а - при температурі $155^{\circ} \mathrm{C}$, тиском 4 МПа, час 2 с; б - при температурі $110^{\circ}$ С з тиском 4 МПа, час 2 c

0,01 с (a) і з найвищою - 6 балів при температурі $155^{\circ} \mathrm{C}$ з тиском $5 \mathrm{MПа,} \mathrm{час} \mathrm{1,5} \mathrm{с} \mathrm{(б).}$

Результати дослідження роздільної здатності відбитка (табл.). Роздільну здатність оцінювали за шестибальною системою з використанням еталонного штампа, що має шість квадратів з лініями товщиною відповідно 1,$5 ; 1,0 ; 0,5 ; 0,4 ; 0,3$ та 0,2 мм. Відбитком у шість балів умовно прийнято вважати той, у якого чітко відтворені всі шість груп ліній тест-об'єкта, без виступів і задирок [10]. Чіткість відбитків визначається візуально по квадратах, що має чіткі проміжки між лініями.

Результати дослідження чіткості зображення (табл.). Комплексний показник якості «чіткість тиснення» включає в себе різкість і роздільну здатність. Чіткість тиснення - це відсутність розмитості, пилкоподібних виступів на краях елементів відбитка. В процесі друку пилковидні виступи на краях елементів відбитка утворюються внаслідок того, що фарба затікає в макропустоти на поверхні зовнішнього матеріалу $[1,11,12]$.
На рис. 2 представлено зразки 3 найменшим відхиленням при температурі $155^{\circ} \mathrm{C}$, тиском $4 \mathrm{MПа,} \mathrm{час} 2$ c (a) і з найбільшим відхиленням при температурі $110^{\circ}$ С з тиском $4 \mathrm{MПа,} \mathrm{час} 2$ с (б).

На рис. 2 спостерігається різниця перенесення фольги при різних технологічних факторах. На відбитку рис. 2, б, спостерігається погана різкість, присутня розмитість, тому такий підбір технологічних режимів не підходить. На відміну від рис. 2, а, де всі лінії відтворились чудово, що свідчить про хороший підбір режиму.

Результати дослідження стійкості до стирання (табл.) дозволяють визначити ступінь міцності фарбового шару фольги при механічній дії на нього. Стирання досліджуваного зразка виконували за допомогою шліфувального паперу вручну поки не почне стиратись фольга. Кількість циклів з шліфувальним папером $\epsilon$ показником міцності відбитка фольги [1].

Результати дослідження адгезії фарбового шару до ПВХ (табл.) дозволяють оцінити міцність закріплення відбитка 
фольги на задруковуваному матеріалі. Суть методу полягає в нанесенні на готове покриття решітчастих надрізів і візуальною оцінкою стану покриття згідно з ГОСТ 15140-78 за чотирибальною системою $[1,3]$.

На рис. 3 представлено результати проведення дослідження адгезії при температурі $110^{\circ} \mathrm{C}$, тиском $4 \mathrm{MПа}$, час $1 \mathrm{c}$ (а), що показує масове відшарування фольги від пластику; на рис. 3, б зразок - при температурі $190^{\circ}$ С з тиском $7 \mathrm{MПа,} \mathrm{час} 1$ c (б).

Результати дослідження графічного спотворення (табл.). Спосіб контролю величини графічних спотворень друкарських елементів штампа для гарячого тиснення полягає у вимірюванні ширини штриха на оригіналі і штриха на штампі. Графічні спотворення у системі «штамп-відбиток», визначається у процентному відношенні відповідно до значень вимірювань, отриманих на мікроскопі, за формулою:

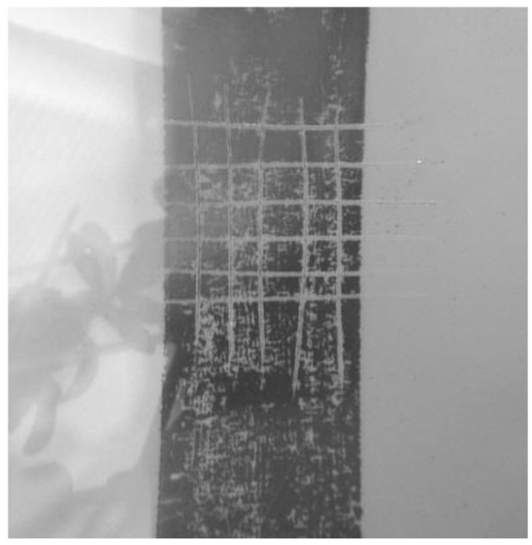

a

$$
\Delta \Gamma_{ш-в}=\left(\frac{Ш_{в}-Ш_{ш}}{Ш_{ш}}\right) 100 \%,
$$

де $\Delta \Gamma_{\text {ш-в }}-$ графічні спотворення в системі «штамп-відбиток»; Ш $_{\text {в }}$ ширина штриха на відбитку; шш - ширина штриха на штампі $[1,10]$.

Аналізуючи результати покривної здатності при різних температурних режимах та тиску можна зробити висновок, що найкращий результат покривної здатності має відбиток, який отриманий при таких режимах: температурі $155^{\circ} \mathrm{C}$, тиском $5 \mathrm{MПа} \mathrm{і} \mathrm{часом} 1$ с, 1,5 с. Отже, саме цей режим рекомендується використовувати для заповнення плашки. Зі збільшенням тиску при тисненні фольгою на непористих матеріалах міцність закріплення фольги на матеріалі зростає до певного періоду. При значному збільшенні тиску міцність закріплення залишається практично незмінною.

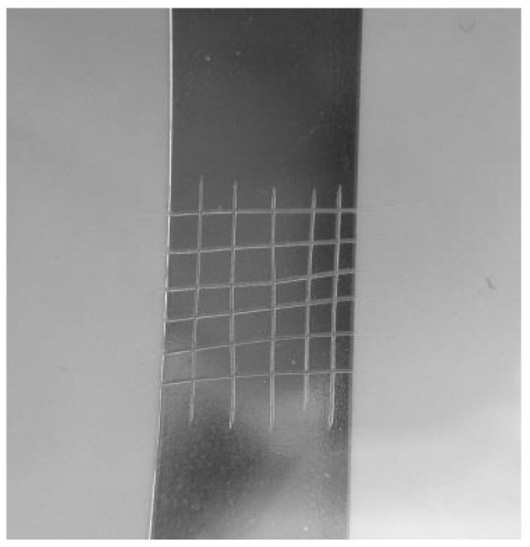

б

Рис. 3. Результати дослідження адгезії а - при температурі $110^{\circ} \mathrm{C}$, тиском $4 \mathrm{MПа,} \mathrm{час} 1$ c; б - при температурі $190^{\circ}$ С з тиском 7 МПа, час $1 \mathrm{c}$ 


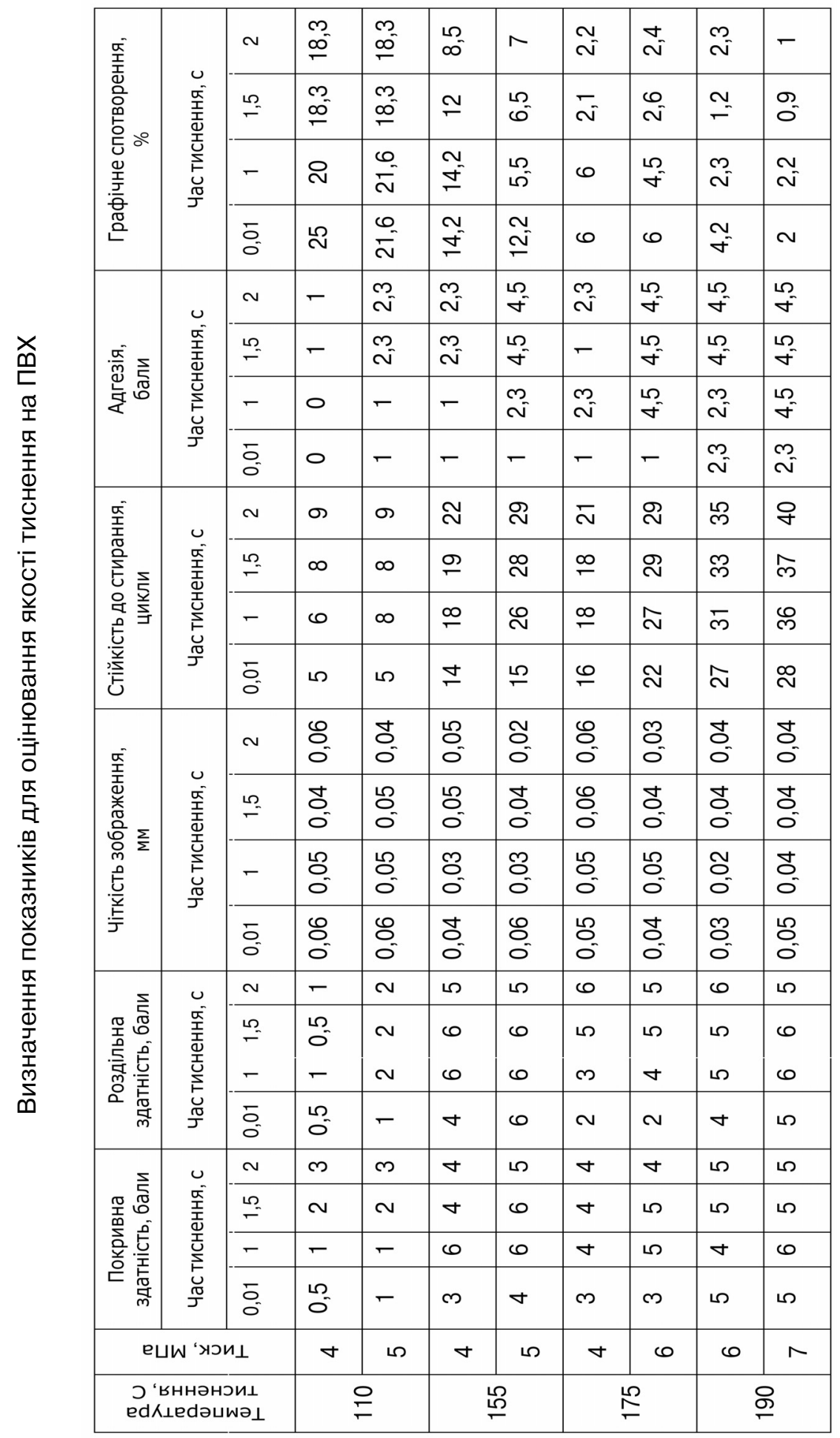


При дослідженні роздільної здатності набрали шість балів відбитки з такими технологічними режимами: температура $155^{\circ} \mathrm{C}$, тиск $4 \mathrm{MПа,} \mathrm{час} \mathrm{тиснен-}$ ня 1 с і 1,5 c; температура $155^{\circ} \mathrm{C}$, тиск 5 МПа, час тиснення 0,5 c, 1 с і 1,5 c; температура $175^{\circ} \mathrm{C}$, тиск $4 \mathrm{MПа,} \mathrm{час} \mathrm{тиснен-}$ ня 2 с; температура $190^{\circ} \mathrm{C}$, тиск $7 \mathrm{MПа,} \mathrm{час} \mathrm{тиснення} 1$ с і 1,5 с. Штампи з вузькими графічними елементами потребують прикладання меншого тиску, а штампи з плашками - максимального.

Результати вимірювань чіткості відбитків на всіх зразках показали, що всі значення знаходяться в межах норми, але технологічний режими при температурі $110^{\circ} \mathrm{C}$ не рекомендується у зв'язку з непродруковуванням тексту.

При дослідженні стійкості до стирання було виявлено, що при збільшенні температури, тиску і часу кількість циклів збільшується, що свідчить про міцність фарбового шару до впливу механічних дій. Тому що з підвищенням температури адгезійна міцність полімерної плівки покриття пластику із шаром фольги збільшується. При зменшенні температури та тиску адгезійна міцність менша, тобто відбиток буде швидко пошкоджуватись, тому не рекомендується застосовувати температурний режим $110^{\circ} \mathrm{C}$.

При збільшенні часу при температурах $175^{\circ} \mathrm{C}$ та $190^{\circ} \mathrm{C}-$ адгезія збільшується при більшому тиску, у нашому випадку - це 6 МПа. 3 підвищенням температури адгезійна міцність полімерної плівки покриття пла- стику із шаром фольги збільшується, що свідчить про дифузійний характер взаємодії фарбового шару фольги і покриття пластику.

При зменшенні температури графічні спотворення дещо зростають так при температурі $110^{\circ} \mathrm{C}$ досягає $25 \%$, що не $є$ хорошим результатам, адже показник знаходиться на грані допуску, а при температурі $190^{\circ} \mathrm{C}$ графічне спотворення досягло $2 \%$, що вказує на оптимальний технологічний режим тиснення.

\section{Висновки}

За результатами проведених експериментальних досліджень зразків тиснення фольгою на ПВХ, отриманих за допомогою різних технологічних факторів можна зробити наступні висновки:

1. Зі збільшенням температури штампу та тиску тиснення, відсоток покривної здатності відбитку на пластику зростає. Найкращий показник покривної здатності спостерігається при температурі $155^{\circ}$ С 3 тиском $5 \mathrm{MПа,} \mathrm{та} 3$ часом 1,5 с. Найгірший показник при температурі $110^{\circ} \mathrm{C}$ з тиском $4 \mathrm{MПа} \mathrm{(на}$ відбитках спостерігається нерівномірне перенесення фольги на пластик).

2. Для якісної передачі зображення необхідно підтримувати в суворо визначених межах температуру кліше. Недостатня температура призводить до неповної передачі фарбового шару фольги на пластик ПВХ, а перегрів кліше - до зміну кольору та втрати дрібних елементів і блиску зображення. Отже, при 
тисненні фольгою найкращі показники чіткості спостерігаються при температурі $190^{\circ} \mathrm{C}$ з тиском 6 МПа та з часом 1с. При температурних режимах $110^{\circ} \mathrm{C}$, та $175^{\circ} \mathrm{C}$, з тиском 4 МПа, та часом 1 с фарбовий шар виходить за межі зображення на 0,06 мм. Тобто при таких технологічних режимах зображення буде неякісне. Для хорошої стійкості для стирання необхідно підбирати відповідний режим тиснення, дослідження показали, що при температурах $190^{\circ} \mathrm{C}$, тиску $7 \mathrm{MПа,} \mathrm{часом} 2$ с отримали 40 циклів, а при температурі $155^{\circ} \mathrm{C}$ з тиском 5 МПа та часом 2 с отримано 29 циклів. Це свідчить про хорошу стійкість до стирання.

3. Графічне спотворення на всіх відбитках лежить в межах норми, хоча при температурі $110^{\circ} \mathrm{C}$ та тиском $4 \mathrm{MПа,} \mathrm{з} \mathrm{часом}$ 0,5 с досягло $25 \%$, що не є хорошим результатом, та 2 \% при температурі $190^{\circ}$ С 3 тиском $7 \mathrm{MПа,} \mathrm{та} \mathrm{часом} \mathrm{0,5} \mathrm{с.} \mathrm{Для} \mathrm{дося-}$ гнення якісного відбитку рекомендовано застосовування саме цього технологічного режиму.

Це ще раз підтверджує, що основою для визначення оптимальних технологічних факторів важливим $€$ проведення практичних досліджень.

\section{Список використаної літератури}

1. Маїк В. 3. Тиснення : технології, матеріали, устаткування / під редакцією д.т.н., проф. Лазаренка Е. Т. - Львів : НВП «МЕТА», 1997. — $174 \mathrm{c}$.

2. Хмілярчук О. І. Оцінка якості гарячого тиснення фольгою на шкірі та замінниках шкіри / О. І. Хмілярчук, К. О. Чепурна, Ю. В. Екгардт // Технологія і техніка друкарства. - 2012. - № 3. - С. 87-96. - Режим доступу : http://ttdruk.vpi.kpi.ua/article/view/32403.

3. Ярка Н. В. Дослідження якості відбитків, одержаних тисненням фотополімерними штампами / Н. В. Ярка, В. З. Маїк // Квалілогія книги. 2011. - № 1. - С. 92-95.

4. Киричок Т. Ю. Вплив температури на перенесення зображення під час гарячого тиснення / Т. Ю. Киричок, Ю.П.Маневич // Технологія і техніка друкарства. - 2008. - № 1. - С. 54-57. - Режим доступу : http://ttdruk.vpi.kpi.ua/article/view/60620.

5. Киричок Т. Ю. Багатофакторне дослідження технологічного процесу тиснення фольгою на пластику / Т. Ю. Киричок, А. М. Мережинська // Вісник жДТУ. - 2011. - № 3. - С. 48-55.

6. Долгова Т. А. Исследование влияния технологических параметров на качество горячего тиснения фольгой / Т. А. Долгова // Труды БГтУ серия «Издательское дело и полиграфия». - 2011. - № 9. - С. 41-45.

7. Маїк В. 3. Теоретичні основи процесів тиснення поліграфічної продукції / В. 3. Маїк // Квалілогія книги. - 2008. - № 2. - С. 43-62.

8. Вакуліч Д. А. Тиснення : класифікація технологій, матеріалів / Д. А. Вакуліч, В. 3. Маїк // Наукові записки. - 2007. - № 2. - С. 130-141.

9. Мартинюк М. С. Визначення показників для оцінювання якості тиснення фольгою на етикетках та пакованнях / М. С. Мартинюк // Квалілогія книги. - 2010. - № 2. - С. 116-117.

10. Слоцька Л. С. Дослідження характеристик відбитків, оздоблених тисненням фольгою / Л. С. Слоцька, А. А. Кривошеєв // Квалілогія книги. 2013. - № 1. - С. 73-76. 
11. Брошюровочно-переплетные процессы. Технологические инструкции / под ред. Н. А. Чернышовой. - М. : Книга, 1982. - 440 с.

\section{References}

1. Maik, V. Z. (1997). Tysnennia: tekhnolohii, materialy, ustatkuvannia [Embossing: technologies, materials, equipment]. Lviv: NVP 'META' [in Ukrainian].

2. Khmiliarchuk, O. I. \& Chepurna, K. O. \& Ekhardt, lu. V. (2012). Otsinka yakosti hariachoho tysnennia folhoiu na shkiri ta zaminnykakh shkiry [Assessment of the quality of hot stamping foil for leather and leather substitutes]. Journal of Tekhnolohiia i tekhnika drukarstva - Technology and Technique of Typography, 3, 87-96. Retrieved from http://ttdruk.vpi.kpi.ua/ article/view/32403 [in Ukrainian].

3. Yarka, N. V. \& Maik, V. Z. (2011). Doslidzhennia yakosti vidbytkiv, oderzhanykh tysnenniam fotopolimernymy shtampamy [Study of the quality of imprints produced by stamping photopolymer stamps]. Journal of Kvalilohiia knyhy - Kvalilogy of Book, 1, 92-95 [in Ukrainian].

4. Kyrychok, T. lu. \& Manevych, lu. P. (2008). Vplyv temperatury na perenesennia zobrazhennia pid chas hariachoho tysnennia [The effect of temperature on the image transfer during hot stamping]. Journal of Tekhnolohiia i tekhnika drukarstva - Technology and Technique of Typography, 1, 54-57. Retrieved from http://ttdruk.vpi.kpi.ua/article/view/60620 [in Ukrainian].

5. Kyrychok, T. lu. \& Merezhynska, A. M. (2011). Bahatofaktorne doslidzhennia tekhnolohichnoho protsesu tysnennia folhoiu na plastyku [A multifactorial study of technological process of foil stamping on plastics]. Journal of Visnyk ZhDTU - Bulletin of Zhytomyr State Technical University, 3, 48-55 [in Ukrainian].

6. Dolgova, T. A. (2011). Issledovanie vlijanija tehnologicheskih parametrov na kachestvo gorjachego tisnenija fol'goj [Research of influence of technological parameters on the quality of hot stamping foil]. Journal of Trudy BGTU serija 'Izdatel'skoe delo i poligrafija' - Proceedings of the Belarusian State Technical University, series 'Publishing and Printing', 9, 41-45 [in Russian].

7. Maik, V. Z. (2008). Teoretychni osnovy protsesiv tysnennia polihrafichnoi produktsii [Theoretical foundations of processes of stamping of printed products]. Journal of Kvalilohiia knyhy - Kvalilogy of Book, 2, 43-62 [in Ukrainian].

8. Vakulich, D. A. \& Maik, V. Z. (2007). Tysnennia: klasyfikatsiia tekhnolohii, materialiv [Embossing: classification of technologies, materials]. Journal of Naukovi zapysky - Scientific Notes, 2, 130-141 [in Ukrainian].

9. Martyniuk, M. S. (2010). Vyznachennia pokaznykiv dlia otsiniuvannia yakosti tysnennia folhoiu na etyketkakh ta pakovanniakh [The determination of indicators for assessing the quality of foil stamping on the labels and packages]. Journal of Kvalilohiia knyhy - Kvalilogy of Book, 2, 116-117 [in Ukrainian].

10. Slotska, L. S. \& Kryvosheiev, A. A. (2013). Doslidzhennia kharakterystyk vidbytkiv, ozdoblenykh tysnenniam folhoiu [Study of the characteristics of the imprints decorated with foil stamping]. Journal of Kvalilohiia knyhy - Kvalilogy of Book, 1, 73-76 [in Ukrainian].

11. (1982). Broshjurovochno-perepletnye processy. Tehnologicheskie instrukcii [Bookbinding processes. Technological instructions]. Moscow: Kniga [in Russian]. 
В статье проведен анализ показателей качества тиснения фольгой образцов с поливинилхлорида при разных технологических режимах. Установлено наиболее оптимальные параметры для получения качественных оттисков.

Ключевые слова: тиснение; фольга; поливинилхлорид; штамп; разрешающая способность; кроющая способность; адгезия; устойчивость к стиранию.

In the article the analysis of indicators of the quality of hot stamping by foil with samples on polyvinyl chloride plastics at different technological modes. The most optimal setting for quality of prints are discovered.

Keywords: embossing; foil; polyvinyl chloride plastics; stamping die; resolution; opacity; adherence; rub resistance. 